\title{
Küçük Konaklama İşletmelerinde Karşılaştırmalı Performans Analizi: Belediye Belgeli Konaklama İşletmeleri Üzerinde Bir Araştırma* \\ (Comparative Performance Analysis of Small Accommodation Enterprises: A Research on Municipality Licensed Accommodation Enterprises)
}

\author{
Vedat YİĞíTOĞLU iD a Melek ŞİRIN iD b \\ a Akdeniz Üniversitesi, Manavgat Turizm Fakültesi, Antalya, Türkiye. viyitoglu@akdeniz.edu.tr \\ b Akdeniz Üniversitesi, Sosyal Bilimler Enstitüsü, Antalya, Türkiye. muhasebemelek@outlook.com
}

\begin{tabular}{|c|c|}
\hline MAKALE BİLGİSİ & ÖZET \\
\hline $\begin{array}{l}\text { Anahtar Kelimeler: } \\
\text { Kücük konaklama isletmeleri }\end{array}$ & $\begin{array}{l}\text { Amaç - Bu araştırmanın amacı, turizmin en önemli bileşenlerinden biri olan küçük ölçekli konaklama } \\
\text { işletmelerinin işletme performansını karşılaştırmalı olarak ortaya koymak ve değerlendirmektir. }\end{array}$ \\
\hline $\begin{array}{l}\text { Veri Zarflama Analizi } \\
\text { Performans, Etkinlik }\end{array}$ & $\begin{array}{l}\text { Yöntem - Araştırma verileri Türkiye'nin en önemli turizm bölgelerinden biri olan Manavgat'ta } \\
\text { bulunan } 25 \text { belediye belgeli konaklama işletmesinde yarı yapılandırılmış görüşme formuyla } \\
\text { toplanmıştır. Veri analizinde girdi odaklı BCC Veri Zarflama Analizi kullanılmışırı. }\end{array}$ \\
\hline Gönderilme Tarihi 17 Nisan & $\begin{array}{l}\text { Bulgular - Analiz sonucunda, konaklama işletmelerinin etkinlik ortalamasının \%71 olduğu, sadece } 8 \\
\text { işletmenin etkin, kalan } 17 \text { 'sinin ise etkin olmadığı ortaya çıkmıştır. Bununla birlikte etkin olmayan } \\
\text { işletmelerin mevcut çıktılarıyla etkin olabilmesi için personel sayısı, oda sayısı, yatak sayısı ve alan } \\
\text { büyüklüklerinden oluşan girdi setinin ortalama } \% 44-56 \text { arasında düşürülmesi gerektiği belirlenmiştir. }\end{array}$ \\
\hline $\begin{array}{l}\text { Revizyon Tarihi } 20 \text { Temmuz } \\
2020\end{array}$ & $\begin{array}{l}\text { Tartışma - Türkiye'deki konaklama işletmelerinin büyük bir bölümü küçük işletme niteliğinde olan } \\
\text { belediye belgeli işletmelerden oluşmaktadır. Bu nedenle ilgili işletmelerin performansı hem turizmi } \\
\text { hem de genel boyutta ekonomiyi belirgin şekilde etkilemektedir. Ancak yazında var olan çalıșmalar }\end{array}$ \\
\hline Kabul Tarihi 10 Eylül 2020 & $\begin{array}{l}\text { daha çok büyük ölçekli işletmeler üzerinde odaklanmaktadır. Bu araştırmanın sonuçları Manavgat'ta } \\
\text { bulunan belediye belgeli konaklama işletmelerinin performansının oldukça düşük düzeylerde } \\
\text { olduğunu ortaya koymaktadır. Düşük performans sonuçlarında aynı zamanda işletmeleri yöneten } \\
\text { sınırlı bilgi, beceri ve kaynaklara sahip işletme sahiplerinin ve bölgede çok sayıda bulunan büyük }\end{array}$ \\
\hline Makale Kategorisi: & $\begin{array}{l}\text { ölçekli işletmelerin önemli etkisinin olduğu düşünülmektedir. Bu nedenle yerel ve merkezi } \\
\text { yönetimlerin özellikle büyük işletmelerin yoğun olduğu bölgelerde ilgili işletmelere daha fazla destek }\end{array}$ \\
\hline Araştırma Makalesi & olması gerekir. \\
\hline
\end{tabular}

Araştırma Makalesi

\section{ABSTRACT}

\begin{tabular}{l} 
ARTICLE INFO \\
\hline Keywords: \\
Small accommodation \\
enterprises \\
Data Envelopment Analysis \\
Performance, Efficiency
\end{tabular}

Received 17 April 2020

Revised 20 July 2020

Purpose - The purpose of this study is comparatively reveal and evaluate the effectiveness of smallsized accommodation enterprises which are one of the most important component of tourism.

Design/methodology/approach - Research data was collected from 25 municipality licensed accommodation establishments operating in Manavgat with semi-structured interview form and analyzed with input-oriented BCC Data Envelopment Analysis.

Findings - As a result of the analysis, it was revealed that the efficiency mean of accommodation enterprises is $71 \%$, only 8 were efficient, and the remaining 17 were not. Addition to that, it was found that ineffective enterprises should decrease their number of rooms, number of beds, number of employees, and enterprise field size by average $44-56 \%$ to be effective with their current outputs.

Accepted 10 September 2020

Discussion - Small accommodation enterprises, most of which are municipality licensed covers large part of accommodation enterprises in Turkey. Therefore, the performance of these enterprises significantly affect both tourism and general economy. However, the studies in the literature mostly

Article Classification: focus on large enterprises. The results of the study indicate that the performance of municipality licensed enterprises is quite low in Manavgat. Business owners who have limited knowledge, skills and resources, and large-sized businesses in the region are also thought to have an impact on the results regarding low performance. For this reason, local and central governments should support the relevant enterprises more, especially in regions where large enterprises are high in number.

*Bu çalışma, 26-28 Eylül 2019 tarihinde Mersin'de düzenlenen 3. International Congress on Future of Tourism: Innovation, Entrepreneurship and Sustainability kongresinde, "Küçük Ölçekli Konaklama İşletmelerinde Etkinlik Analizi” başlı̆̆ı ile sunulmuş bildirinin gözden geçirilmiş ve genişletilmiş halidir.

\section{Önerilen Atıf/ Suggested Citation}

Yiğitoğlu, V., Şirin, M. (2020). Küçük Konaklama İşletmelerinde Karşılaştırmalı Performans Analizi: Belediye Belgeli Konaklama İşletmeleri Üzerinde Bir Araştırma, İşletme Araştırmaları Dergisi, 12 (3), 2297-2311. 


\section{Giriş}

İşletme performansının kapsamlı ve uygun şekilde ortaya koyulması, başarılı işletme faaliyetlerinin temel koşullarından biri olarak görülmektedir (Kaplan ve Norton, 2001: 88; Sainaghi, 2010: 920). Ancak bu performansın etkin bir şekilde ortaya koyulması kolay değildir. Çünkü işletme performansı tek bir şekilde değil, birbirinden farklı bir takım göstergeler üzerinden değerlendirilmektedir (Bititci vd., 2016: 1585). Bu göstergeler arasında en fazla önem atfedilen ve en yaygın kullanılanların başında ise etkinlik gelmektedir (Akal, 2005: 179; De Jorge ve Suarez, 2014: 354). Bu bağlamda Neely vd. (1995: 80), performans ölçümünü bir faaliyetin etkinlik düzeyinin niceliksel olarak belirlenme süreci olarak tanımlamıştır.

Uygulamada işletme etkinliğinin ölçümü adına geliştirilmiş oran analizi, regresyon analizi, başa baş analizi ve gelir yönetimi gibi değişik yöntemler bulunmaktadır (Barros ve Mascarenhas, 2005: 421; De Jorge ve Suarez, 2014: 354). Bunlar arasında Veri Zarflama Analizi (VZA), diğer yöntemlerin kısıtlarını barındırmaması ve daha esnek koşullara sahip olması bakımından bir adım öne çıkmaktadır. Nitekim Parkan (1996: 281) tarafından otel işletmeleri örnekleminde yapılmış bir araştırmada, VZA ile elde edilen sonuçların oran analizi ile elde edilen sonuçlardan daha iyi ve daha anlaşılır olduğu sonucuna varılmıştır. VZA göreceli performans analizi için geliştirilmiş doğrusal programlama esaslı basit ve çok yönlü parametrik olmayan bir tekniktir (Babacan ve Özcan, 2009: 178; Tone, 2017: 142). Diğer performans ölçüm yöntemlerine göre en belirgin avantaj1; farklı sayı ve nitelikteki değişkenleri birlikte değerlendirebilmesi ve performansı iyi olmayan birimlerin geliştirilmesi için somut hedefler ortaya koyabilmesidir (Charles ve Kumar, 2012: 152). Genellikle küçük olarak nitelendirilen belediye belgeli konaklama işletmelerinin performansında maliyet, satış miktarı, satış gelirleri gibi verilerle birlikte işletmenin imajı, konumu, hizmetleri, konuk memnuniyeti, işletme sahiplik yapısı ve personel özellikleri gibi farklı nitelikte çok sayıda etmen etkili olabilmektedir. Bu nedenle ilgili otellerin performansının VZA ile kapsamlı olarak ortaya konulması önemlidir.

Belediye belgeli konaklama işletmeleri genellikle küçük ölçekli işletme özelliklerine sahiptir (Cetinel vd., 2009: 44). Bu bağlamda küçük ölçekli işletmeler için ifade edilen hususlar belediye belgeli işletmeler için de geçerli olmaktadır. Birçok yazar küçük konaklama işletmelerinin turizmle birlikte ekonomiye, istihdama, bölgesel kalkınmaya, toplumsal refaha, sağlıklı gelir dağılımına ciddi katkılar sağladığını ifade etmektedir (Morrison, 1998; Komppula ve Reijonen, 2006; Akbaba, 2012; Ye vd., 2019). Dolayısıyla bu tür işletmelerin varlığı ya da gelişimi sadece sektör temsilcileri değil, başta yerel paydaşlar olmak üzere toplumun tüm taraflarını bir şekilde etkilemektedir. Ancak turizm alan yazını incelendiğinde ilgili çalışmaların genellikle büyük ölçekli konaklama işletmeleri üzerinde odaklandığı, küçük işletmeleri dikkate alan çalışma sayısının ise oldukça sinırlı olduğu görülmektedir (Ahmad ve Muhammad Arif, 2016; Morrison ve Teixeira, 2004; Morrison ve Conway, 2007; Thomas, 2000). Benzer bir durum ulusal yazında da söz konusudur (Akbaba, 2012; Cetinel vd., 2009). Bu bağlamda sadece belediye belgeli konaklama işletmeleri örnekleminde yapılacak çalışmaların, küçük ölçekli konaklama işletmeleriyle ilgili alan yazınına katkı sağlaması beklenir.

\section{Kavramsal Çerçeve}

\subsection{Küçük Ölçekli Konaklama İşletmeleri}

Küçük işletme kavramı konusunda standart ya da genel kabul görmüş bir tanım bulunmamaktadır. Öyle ki yirmi yılı aşkın bir zaman öncesinde Atkins ve Lowe (1997: 42), yazında 40'tan fazla farklı küçük ve orta büyüklükteki işletme tanımı olduğunu ifade etmiştir. Bununla birlikte Avrupa Birliği 50'den az çalışanı olan ve yıllık satışları 10 milyon Avro ve altında olan işletmeleri küçük işletme olarak kabul etmektedir. Ülkemizde ise Küçük ve Orta Büyüklükteki İşletmelerin Tanımı, Nitelikleri Ve Sınıflandırılması Hakkında Yönetmelik ile personel sayısı aynı şekilde 50'den az, ancak yıllık net satışları 25 Milyon TL'yi aşmayan işletmeler küçük olarak nitelendirilmektedir (Mevzuat Bilgi Sistemi, 2019). Küçük konaklama işletmesi tanımında da benzer bir durum söz konusudur. Bazı yazarlar 50, bazı yazarlar 25, bazı yazarlar ise 15 odaya kadar odası olan otelleri küçük olarak ifade ederken, bazı yazarlar ise 50, 25 ya da 10 kişiye kadar çalışanı olan otelleri küçük olarak belirtmektedir (Buhalis ve Main, 1998: 198; Thomas, 2000: 346; Ahmad ve Muhammad Arif, 2016: 290). Diğer taraftan zamanla konaklama işletmelerinin kapasiteleri artmaya başlamış ve böylece küçük olarak nitelendirilen otellerin oda sayıları da yükselmiştir. Özellikle gelişmiş ülkelerde son yıllarda yapılan çalışmalarda 100'ün altında odası olan otellerin küçük olarak kabul edildiği görülmektedir (Chibili, 2017: 56). Küçük konaklama işletmelerinin personel sayısı ve oda kapasitesi dışında oda fiyatı, yıldız durumu, işletme türü ve yönetim şekli gibi ayırt edici bir takım özellikleri daha vardır. Örneğin 3 yıldız ve altında yıldızı olan 
işletmeler ile belediye belgeli işletmeler genellikle küçük ve orta büyüklükte işletme (KOBI) olarak nitelendirilmektedir (Cetinel vd., 2009: 44). Diğer taraftan küçük ölçekli konaklama işletmelerinin daha çok şahıs işletmesi olarak kurulduğu, ikinci ya da üçüncü bölge olarak adlandırılan merkezin dışındaki yerlerde konumlandığı, nispeten daha düşük oda fiyatlarına sahip olduğu ve bizzat işletme sahibi tarafından yönetildiği bilinmektedir (Avcıkurt vd., 2011; Morrison, 1998; Morrison ve Conway, 2007).

Konaklama işletmelerinde performans kavramı, genellikle doluluk oranı, pazar payı, personel sayısı ve personel ya da müşteri başına elde edilen gelirle ilişkilendirilmiştir (Sharma ve Sneed, 2008; Sainaghi, 2010; Assaf ve Tsionas, 2018). Bunlar arasında özellikle doluluk oranı uygulamacılar tarafından en yaygın kullanılan ölçüt olarak ön plana çıkmaktadır (Rey-Marti vd., 2017: 2089). Ancak doluluk oranın tek başına işletme performansını ya da karlılığını yansıtmada yeterli olmadığını belirtmek gerekir. Çünkü yüksek oda fiyatları ya da düşük maliyetler nedeniyle doluluk oranları düşük işletmeler daha karlı olabilmektedir. Diğer taraftan sadece iki sayısal veriyle elde edilen doluluk oranı (satılan oda sayısı/satışa sunulan oda sayısı şeklinde) mevcut ya da geçmiş performansı yansıtmakta, gelecek hakkında anlamlı bilgiler vermemektedir. Bununla birlikte hizmet işletmeleri açısından hayati derecede öneme sahip olan müşteri memnuniyeti, personel bağlllı̆̆ ve hizmet kalitesi gibi finansal olmayan unsurlar ise ya finansal verilerin gerisinde kalmakta ya da finansal verilerden ayrı olarak değerlendirilmektedir. Bu nedenle günümüz pazar koşullarında varlıklarını korumak ya da geliştirmek isteyen işletmeler, performanslarını etkileyen finansal ve finansal olmayan nitelikteki unsurları birlikte dikkate alan daha kapsamlı ve daha esnek performans ölçüm yöntemlerine gereksinim duymaktadır (Kaplan ve Norton, 2001: 89; Bergin-Seers ve Jago, 2007: 146). Farklı sayı ve farklı nitelikteki çoklu girdi ve çoklu çıktı değişkenlerini birlikte ele alan VZA, bu gereksinimi karşılayabilecek belli başlı performans ölçüm yöntemlerinden biridir.

\subsection{Belediye Belgeli Konaklama İşletmeleri}

Türkiye'de konaklama işletmeleri hukuki bakımdan bakanlık belgeli ve belediye belgeli olmak üzere ikiye ayrılmaktadır. Bakanlık belgeli olanlar Kültür ve Turizm Bakanlığı'nın, belediye belgeli olanlar ise bulundukları bölgedeki yerel yönetimlerin denetimi altında faaliyetlerini yerine getirir. Bakanlık belgesi kendi içinde ayrıca turizm yatırım belgesi ve turizm işletme belgesi şeklinde ikiye ayrılmaktadır. Turizm yatırım belgesi adından anlaşıldığı üzere yatırım aşamasında geçerli olan belge türüdür. Yatırımını tamamlamış ya da aktif şekilde çalışan işletmelerin turizm işletme belgesi alması gerekir. Belediye belgeli konaklama tesisleri ise otel, motel, pansiyon, tatil köyü, kamping, kaplıca ya da kamu misafirhanesi şeklinde işletme türleriyle ruhsatlandırılmaktadır. Kültür ve Turizm Bakanlığı'nın 2018 yılı verilerine göre toplam oda kapasitesi 464.927 olan 3.925 turizm işletme belgeli tesis, toplam oda kapasitesi 231.001 olan 7.671 belediye belgeli tesis bulunmaktadır (Kültür ve Turizm Bakanlığı, 2019). Dolayısıyla toplam konaklama tesislerinin yaklaşık \%66 gibi büyük bir kısmını oluşturan belediye belgeli tesislerin ortalama oda sayısı 30'dur. Bu ortalamadan hareketle belediye belgeli konaklama işletmelerinin küçük işletme olarak nitelendirmek mümkündür.

\subsection{Veri Zarflama Analizi}

Performans işletme yazınında en yaygın kullanılan kavramlardan biridir. Öyle ki bu kavram, insanlar için olduğu kadar işletmeyi oluşturan malzeme, araç-gereç, sermaye, kaynaklar, varlıklar ve çevre unsurları gibi tüm bileşenler için geçerli olabilmektedir. İşletme çevresinde performans kavramı, genellikle iş gören, birim, faaliyet ve işletme (örgütsel) performans olmak üzere çeşitli açllardan ele alınabilmektedir. Örgütsel olarak değerlendirildiğinde performans, bir işletmenin belirli bir zaman diliminde elde ettiği başarı derecesi olarak tanımlanmaktadır. Daha genel bir şekilde ele alındığında ise performans; bir işi yapan bireyin, grubun ya da örgütün amaçlanan hedeflere ne düzeyde ulaşabildiğinin nicel ve nitel olarak gösterilmesidir (Oktay ve Özgür, 2008: 164).

İşletme yazınında performans kavramı, tek bir unsur ya da etmen üzerinden değil, genellikle çok çeşitli unsurların ya da boyutların bir araya gelmesinden oluşan bir olgu olarak dikkate alınmaktadır. Örneğin Sink (1985) örgütsel performansın verimlilik, etkinlik, etkililik, kalite, karlılık, iş yaşam kalitesi ve yenilik olmak üzere yedi farklı boyutla ölçülebileceğini ifade etmektedir (Haynes, 2007: 147). Bu boyutlar arasında en önemli olanları verimlilik ve etkinliktir (Akal, 2005: 179; Shahzad vd., 2012: 982). Verimlilik ya da diğer adıyla üretkenlik, en basit haliyle çıktının girdiye oranıdır. Dolayısıyla verimlilik, bir işletmenin üretim sürecinde kullandığı girdilerle elde ettiği çıtılar arasındaki ilişkiyi yansıtmaktadır (Prokopenko, 2005: 19). Etkinlik ise işletmedeki çıktılar ve girdiler arasındaki sebep-sonuç ilişkisinin nasıl olduğunu ölçerek daha kapsamlı ve 
daha nesnel bir yaklaşım ortaya koymaktadır (Yükçü ve Atağan, 2009: 7). Etkinlik kavramı, matematiksel hesaplama yöntemi olarak da verimlilik kavramından ayrılmaktadır. Verimlilik bir referans noktasına ihtiyaç duyulmadan, yalnız bir karar verme birimi için hesaplanabilecek göreli olmayan bir performans göstergesidir. Ancak göreli bir kavram olan etkinliğin hesaplanabilmesi için mutlaka birden fazla karar verme birimi olmalıdır (Budak, 2011: 96). Yerli bir mağaza grubunun başkanı Cem Boyner'e göre işletme boyutunda verimlilik, zaten yaptığınız bir işi biraz daha geliştirmek, belki bir aşama yukarı çekmektir. Oysa etkinlik, stratejik bir karardır. Çünkü etkinlik sadece işletmeyi değil, pazarı ve pazarın geleceğini de ele almaktadır. Bu nedenle örgütsel boyutta verimlilik ve etkinlik arasında bir kıyaslama yapılması durumunda, etkinlikten yana bir tercihin yapılması gerekir (Capital, 2013).

Yapılan çalışmada performans göstergesi olarak işletme etkinliği dikkate alınmıştır. İşletme etkinliğinin ölçülmesi ve değerlendirilmesinde en yaygın kullanılan yöntemlerden biri de VZA'dır (Ramanathan, 2003; Avkıran ve Parker, 2010; Haksever ve Render, 2013; Tone, 2017). VZA, benzer girdiler kullanarak benzer çıtılar üreten karar birimlerinin etkinliklerini, karşılaştırmalı olarak ölçmeyi sağlayan doğrusal programlama tabanlı bir performans değerlendirme yöntemidir (Banker vd., 1984: 1088; Özdemir ve Demireli, 2013: 216). Özellikle oran analizi ve regresyon analizi gibi parametrik yöntemlerin kısıtlarını barındırmayan bu yöntem, doğru bir şekilde kullanıldığında oldukça güçlü bir yönetim aracı olabilmektedir. VZA'yı diğer performans değerleme yöntemlerinden ayıran başlıca etmenler şunlardır (Ramanathan, 2003: 173-174; Charles ve Kumar, 2012: 1-2; Haksever ve Render, 2013: 314-315);

$\checkmark$ VZA girdi ve çıtıların nasıl olması gerektiğine dair ön koşul gerektirmez. Farklı sayılarda ve farklı nitelikte girdi ve çıktı değişkenleri analizde kullanılabilir. Bununla birlikte sadece işletme içi değil, hava durumu, ekonomik durum ve demografik unsurlar gibi işletme dışı faktörler de analize dâhil edilebilmektedir.

$\checkmark$ VZA, etkin olmayan Karar birimlerinin (KB) etkin olabilmesini sağlayacak girdi ve çıktı değişiminin nasıl ve ne kadar olması gerektiğini net bir şekilde ortaya koymaktadır. Analiz sonunda ayrıca etkin KB dikkate alınarak, etkin birimlerde olması muhtemel karakteristik özellikler de belirlenebilmektedir.

$\checkmark$ Regresyon analizinden farklı olarak VZA, üretim etkinliği için birden fazla yol olduğunu varsayarak, KB üzerinde bireysel şekilde odaklanmaktadır. Yani farklı girdi ve çıktı bileşenleri ile olası etkinlik sağlanabilmektedir. Bunun sonucu olarak etkin olmayan karar biriminin etkinliğini referans grubunda etkin olan karar birimlerinin seviyesine çıarmak için tek bir yol değil, pek çok alternatif yol üretmektedir.

$\checkmark$ Tipik istatistiksel yöntemler merkezi eğilim yaklaşımları özelliğindedir ve bu yaklaşımlarda ortalama değerlere göre göreceli etkinlik değerlendirilmektedir. VZA ise uç noktalı bir yöntemdir ve her karar birimi sadece en iyi birim ya da birimlerle karşılaştırılır.

$\checkmark$ Parametrik yöntemlerin aksine girdi ve çıktı arasında fonksiyonel bir bağıntıya ihtiyaç duymayan VZA, üretim fonksiyonunun analitik yapısı hakkında herhangi bir ön varsayım gerektirmez, dolayısıyla parametrik yöntemlere göre daha esnektir. Dahası küçük örneklem düzeylerinde dahi iyi şekilde uygulanabilmektedir.

İlk VZA modeli 1978 yılında ölçeğe göre sabit getiri (ÖSG) varsayımıyla Charnes, Cooper ve Rhodes (CCR) geliştirilmiştir. ÖSG varsayımı, girdilerdeki değişim oranın çıktılarda da aynı oranda bir değişime neden olacağı anlayışına dayanmaktadır. Bu varsayım sadece uygun ölçekte faaliyetin yürütüldüğü firmalarda geçerli olabilmektedir. Ancak rekabet ve değişen pazar koşullarında firmaların en uygun ölçekte faaliyet göstermesi genellikle mümkün olmamaktadır. Bu nedenle sonraki yıllarda girdi değişimi ile çıktı değişimi arasında her zaman doğrusal bir ilişki olmadığı ileri sürülmüş ve 1984 yılında Banker, Charnes ve Cooper (BCC) tarafından ölçeğe göre değişen getiri (ÖDG) varsayımıyla yeni bir VZA modeli geliştirilmiştir. Ölçeğe göre değişken getiri modeli nispeten daha esnektir ve ölçeğe göre farklı değerler sağlayabilmektedir. BCC modelinde veriler daha sıkı bir şekilde zarflanmakta ve bunun sonucu olarak da CCR modelinde elde edilen etkinlik skorlarından daha yüksek ya da en az ona eşit düzeylerde etkinlik skorları sağlanmaktadır. Bu bağlamda BCC modelinde, CCR modeline kıyasla daha fazla sayıda KB etkin olarak ortaya çıkmaktadır. Her iki VZA modeli odaklanma biçimine göre girdi odaklı, çıktı odaklı ve odaksız olmak üzere üç farklı türü bulunmaktadır. Ancak uygulamada genellikle girdi ve çıktı odaklı olmak üzere iki şekilde kullanılmaktadır Wöber, 2000; Sigala, 2004; Sharma ve Sneed, 2008; Yılmaz, 2013; Fernandez ve Becerra, 2015). Girdi odaklı modeller, karar birimlerinin etkin olması için çıktıları sabit tuturak, girdilerin ne düzeyde azaltılması 
gerektiğini; çıktı odaklı modeller ise tam tersi girdileri sabit tutarak çıktıları ne düzeyde arttırılması gerektiğini ortaya koymaktadır.

VZA, geliştirildiği ilk yıllardan itibaren hem işletme çevrelerinde hem de akademik çevrelerde giderek artan şekilde değer görmüş, bunun sonucu olarak da çok sayıda bilimsel çalışmaya ve uygulamaya konu olmuştur. Öyle ki mevcut VZA yazınında savunma, eğitim, sağlık, ekonomi, üretim, finans ve pazarlama başta olmak üzere 30'un üzerinde farklı endüstriyi kapsayan küresel ölçekte binlerce çalışma bulunmaktadır (Wöber, 2007; Avkıran ve Parker, 2010; Liu vd., 2013). Turizm endüstrisinde ilk VZA uygulama çalışmaları özellikle restoran sektöründe, 1986 yılında yapılmıştır (Hruschka, 1986; Banker ve Morey, 1986). Otel işletmelerini kapsayan ilk çalışmalar ise yaklaşık on yıl sonra Baker ve Riley (1994) ile Parkan (1996) tarafından gerçekleştirilmiştir. Ulusal turizm yazınında, en eski VZA uygulaması olarak Tarım, Dener ve Tarım (2000) tarafından yapılmış araştırmaya ulaşılmıştır. Bu araştırmada yazarlar Antalya'da bulunan 10'u beş, 11'i dört yıldızlı olmak üzere toplam 21 konaklama işletmesinin etkinliklerini karşılaştırmalı olarak analiz etmiştir. Analiz sonunda dört yıldızlı otellerin etkinlik ortalamasının $\% 72$, beş yıldızlı olanların etkinlik ortalamasının ise $\% 52$ olduğu ortaya koyulmuştur. Aksu ve Köksal (2005) ise Antalya bölgesinde zincir ve bağımsız toplam 24 adet beş yıldızlı otelin etkinliklerini karşılaştırmıştır. Araştırma sonunda sadece 9 otelin etkin olduğu, bununla birlikte zincir ve bağımsız otellerin etkinlikleri arasında anlamlı bir farklılık olmadığı tespit edilmiştir. Babacan ve Özcan (2009) ise Alanya bölgesinde bulunan 22 otelin etkinliklerini girdi ve çıtı odaklı VZA yöntemiyle analiz etmiş ve analiz sonrasında 13 otelin (\%59) etkin olduğunu belirlemiştir. Daha sonra Uyar ve Alış (2013: 107) tarafından yine Alanya'da 37 adet beş yıldızlı konaklama işletmesi örnekleminde yapılan başka bir araştırmada ise sadece 5 işletmenin (yaklaşık \%14'ünün) etkin olduğu sonucuna varmıştır.

Genel olarak bakıldığında eğitim, sağlık ve devlet kurumları gibi kar amacı olmayan kurumlarda yapılanlar kadar olmasa da, turizm alanında da oldukça fazla sayıda VZA çalışması bulunmaktadır. Konaklama işletmeleri örnekleminde son yirmi yıl içinde yapılmış bu çalışmalardan bazıları aşağıda yer alan Tablo 1.'de, en güncel olanından başlayarak kronolojik olarak sıralanmıştır. Tabloda görüldügüü üzere VZA, konaklama işletmeleri örnekleminde uluslararası düzeyde kabul görmüş oldukça yaygın bir yöntemdir. Farklı ülkelerde yapılmış çalışmalarda genellikle temel VZA modelleri olan CCR ve BCC modelleri hâkim olmuştur. Bununla birlikte tablodan da anlaşıldığı gibi karar birimi olarak dikkate alınan işletmeler genellikle orta ya da büyük ölçekli işletmeler olmuştur.

Tablo 1. Konaklama İşletmeleri Örnekleminde Yapılmış Bazı VZA Çalışmaları

\begin{tabular}{llll}
\hline Referans & Ülke & Karar Birimi & VZA Modeli \\
\hline Poldrugovac vd. (2016) & Hırvatistan & 100 Otel & Çıktı BCC \\
\hline Fernandez ve Becerra (2015) & İspanya & 166 Otel & Çıktı CCR \\
\hline Sami ve Mohamed (2014) & Tunus & 27 Otel & Çıktı VZA \\
\hline Yılmaz (2013) & Türkiye & 41 Lüks otel & Girdi ve Çıktı BCC \\
\hline Lin vd. (2013) & Tayvan & 25 Lüks otel & CCR ve BCC \\
\hline Manasakis vd. (2013) & Yunanistan & 50 Lüks otel & Girdi CCR ve BCC \\
\hline Honma ve Hu (2012) & Japonya & 15 Otel & Girdi BCC \\
\hline Pulina vd. (2010) & İtalya & 21 Bölge oteli & Girdi BCC \\
\hline Min vd. (2009) & Kore & 31 Lüks otel & CCR ve BCC \\
\hline Sharma ve Sneed (2008) & Tanzanya & 38 Küçük otel & Girdi CCR ve BCC \\
\hline Barros ve Dieke (2008) & Angola & 12 Otel & Girdi CCR \\
\hline Zhou vd. (2008) & Çin & 31 Bölge oteli & Çıktı CCR ve BCC \\
\hline Barros ve Santos (2006) & Portekiz & 15 Otel & Çıktı CCR ve BCC \\
\hline Sigala (2004) & İngiltere & 93 Otel & Çıktı CCR \\
\hline Wöber (2000) & Avusturya & 61 Otel & Girdi CCR \\
\hline
\end{tabular}




\section{Yöntem}

Araştırmanın temel amacı, küçük ölçekli konaklama işletmelerinin işletme performansını karşılaştırmalı olarak ortaya koymak ve değerlendirmektir. Bu bağlamda cevabı aranan başlıca araştırma soruları şunlardır:

Küçük ölçekli konaklama işletmelerinin etkinlik performansı ne düzeydedir?

Etkin olmayan küçük konaklama işletmeleri nasıl etkin hale getirilebilir?

Araştırma evrenini küçük ölçekli işletme niteliğinde olmaları bakımından belediye belgeli konaklama işletmeleri oluşturmaktadır. Daha önce de ifade edildiği gibi ülkemizdeki konaklama işletmelerinin büyük bir kısmını belediye belgeli işletmeleri oluşturmaktadır. Örneklemin mümkün olabildiğince homojen olması için çalışma evreni, Antalya Manavgat bölgesiyle sınırlandırılmıştır. Manavgat, turizm bakımından Türkiye'nin en büyük ve en önemli merkezlerinden biridir. Öyle ki Antalya'nın toplam yatak kapasitesinin yaklaşık üçte biri Manavgat'ta bulunmaktadır. 2018 yılı itibari ile Manavgat bölgesinde Turizm Belgeli 229, Belediye Belgeli 282 olmak üzere toplam 511 konaklama tesisi yer almaktadır (Manavgat Ticaret ve Sanayi Odası, 2018).

2019 yılı Mayıs ayı içinde kolayda örnekleme ve amaçlı örnekleme yöntemleri birlikte kullanılarak belirlenen ve araştırmaya katılmayı kabul eden 25 belediye belgeli konaklama işletmesinden yarı yapılandırılmış görüşme formuyla veriler toplanmıştır. Görüşme formu hazırlanırken öncelikle kapsamlı bir yazın taraması yapılmıştır. Bu kapsamda konaklama işletmeleri örnekleminde yapılmış ulusal ve uluslararası çalışmalar incelenmiştir. Yapılan incelemeler sonunda ilgili çalışmalarda kullanılan girdi ve çıktı değişkenlerinin genellikle iki farklı şekilde toplandığı görülmüştür. Bunlardan ilki söz konusu verilerin turizm ofisi, belediye ve turizm örgütleri gibi yerel, bölgesel ya da merkezi istatistik birimlerinden elde edilmesi, ikincisi ise verilerin araştırmacı tarafından görüşme yoluyla toplanmasıdır. Türkiye'de bulunan küçük konaklama işletmeleri ve bunların faaliyetleri konusunda herhangi bir veri kaydı bulunmadığından ikinci veri toplama şeklinin kullanılmasına karar verilmiştir. Araştırma amacına bağlı olarak hazırlanan görüşme formu turizm alanında uzman üç farklı akademisyenin ve bir küçük otel yöneticisinin değerlendirmesine sunulmuştur. Böylece görüşme formunun içerik geçerliliğinin desteklenmesi amaçlanmıştır. Yapılan değerlendirmelere göre görüşme formu içerik ve biçimsel olarak düzenlenmiş ve nihai şeklini almıştır. Görüşme formu temel olarak iki bölümden oluşmaktadır. İlk bölümde işletme ile ilgili tanımlayıcı sorular, ikinci bölümde ise işletmenin 2018 yılına ilişkin faaliyet sonuçlarıyla ilgili sorular yer almaktadır. Görüşmeler, işletme sahip ve yöneticilerine yönelik olarak yüz yüze gerçekleşmiş ve ortalama 10-12 dakika sürmüştür.

Yapılan görüşmelerde müşteri memnuniyetiyle ilgili işletmelerde güvenilir bir kayıt sisteminin olmadığ1 anlaşılmıştır. Bu nedenle mümkün olabildiğince objektif olabilmesi adına müşteri memnuniyeti olarak tripadvisor sitesindeki puanlar kullanılmıştır. Araştırmada toplanan verilerinin analizde, girdi odaklı BCC VZA modeli kullanılmıştır. Daha önce de ifade edildiği gibi VZA uygulamalarında temel olarak ölçeğe göre sabit getiri varsayımı altında (CCR) ve ölçeğe göre değişken getiri varsayımı altında (BCC) olmak üzere iki farklı model kullanılmaktadır. BCC modeli, CCR modeline göre daha esnek ve değişen faaliyet koşullarına daha duyarlıdır (Ramanathan, 2003). BCC modeli özellikle optimum düzeyde faaliyetlerini sürdüremeyen işletme ya da birimler için önerilmektedir (Banker, Charnes ve Cooper, 1984; Honma ve Hu, 2012, Yılmaz, 2013). Mevcut rekabet ve piyasa koşullarında diğer turizm işletmeleri gibi belediye belgeli küçük otellerin en iyi düzeyde faaliyetlerini sürdürmesi çok zordur. Bununla birlikte küçük işletme yöneticilerinin çıktılar üzerinde denetim gücü de oldukça sınırlı kalmaktadır. Dolayısıyla küçük işletme yöneticilerinin girdiler üzerinde denetim ya da etki gücü daha fazla olduğu düşünülmektedir. Bu nedenle belediye belgeli konaklama işletmelerinin performans analizinde girdi odaklı BCC modeli kullanılmıştır. Veri analizi ise Win4DEAP (Data Envelopment Analysis Program) ve EMS 1.3 (Efficiency Measurement System) programlariyla gerçekleştirilmiştir. Analizde iki programının kullanılmasının başlıca nedeni ilgili programların yeterlilikleriyle ilgilidir. Çünkü DEAP programında "süper etkinlik" yani etkin birimler arasında etkinlik bakımından sıralama yapılamamakta, EMS programında ise etkin olmayan KB için hedeflenen girdi ve çıktı değerleri net bir şekilde gösterilmemektedir. İki program sayesinde bir taraftan daha etkin ve daha kapsamlı sonuçlara ulaşılması kolay hale gelmekte, diğer taraftan da ölçüm güvenirliliği artmaktadır.

\section{Bulgular}

Araştırmaya dâhil olan belediye belgeli konaklama işletmelerinin \%76 gibi büyük bir kısmını oteller (19 işletme), kalanını ise moteller (4 işletme) ve pansiyonlar ( 2 işletme) oluşturmaktadır. Büyük bir kısmı (22 adet) 
işletme sahibi tarafından yönetilen bu işletmelerden $18^{\prime} \mathrm{i}$ sezonluk, $7^{\prime}$ si ise sürekli olarak faaliyetini sürdürmektedir. Sezonluk faaliyet verisine bakarak Manavgat'ta bulunan belediye belgeli işletmelerin, bölgedeki büyük işletmeler gibi tatil turizmine odaklandığını söylemek mümkündür.

VZA uygulamalarında karar birimlerinin performansı, kullanılan girdi ve çıktı değişkenlerine bağlı olarak ortaya koyulmaktadır. İşletme performansı açısından önemli olan bir değişkenin analiz sürecine dâhil edilmemesi ya da eksik bir şekilde dikkate alınması yanıltıcı sonuçlar doğurabilmektedir. Bu bağlamda doğru ve güvenilir sonuçların elde edilmesi için işletme faaliyetlerini en iyi yansıtan değişkenlerin kullanılması gerekir. Söz konusu değişkenler belirlenirken verilerin elde edilebilirliği, alan yazını ve uzman kişilerin görüşleri olmak üzere üç farklı yöntemden yararlanılmaktadır. Yapılan yazın incelemesi sonunda malzeme giderleri, işçilik giderleri, oda sayısı, yatak kapasitesi ve personel sayısının en yaygın kullanılan girdi değişkenleri; müşteri memnuniyeti, doluluk oranı ve oda gelirinin ise en yaygın kullanılan çıkı değişkenleri olduğu anlaşılmaktadır (Poldrugovac vd., 2016; Uyar ve Alış, 2014; Doğan ve Tanç, 2008; Aksu ve Köksal, 2005; Barros, 2005; Tarım vd., 2000). Ancak veri toplama sürecinde katılımcllar işletmeleriyle ilgili maliyet ve gelir gibi finansal bilgilerini paylaşma konusunda çekimser bir tutum sergilemiştir. Bu nedenle giderler ya da operasyonel masraflar girdi veri seti içinde kullanılamamıştır. Bununla birlikte oda geliri ise doğrudan değil, doluluk oranı ve ortalama oda fiyatı üzerinden hesaplanarak analiz sürecine dahil edilmiştir. Küçük ölçekli konaklama işletmeleri fiziksel alan bakımından da orta ve büyük ölçekli işletmelerden ayrılmaktadır. Bu bağlamda alan büyüklüğü önemli bir girdi değişkeni olarak analiz sürecine dâhil edilmiştir. Diğer taraftan küçük oteller konuklarıyla daha samimi ve daha yakın ilişkiler kurabilmekte, onların kendilerini daha fazla misafir gibi hissetmelerini sağlayabilmektedir (Mohammad, 2016; 64; Barros ve Mascarenhas, 2005: 420). Bu durum konukların tutumlarını olumlu etkilemekte ve otele tekrar gelme olasılıklarını da arttırmaktadır. Dolayısıyla küçük ölçekli işletmelerde tekrar gelen müşteri oranlarının yüksek olması beklenir. Bu bağlamda tekrar gelen müşteri oranında da çıkı değişkeni olarak kullanılmasına karar verilmiştir. Bu açıklamalar ışığında yapılan çalışmada girdi değişkeni olarak oda sayısı, yatak sayısı, personel sayısı ve alan büyüklüğü; çıtı değişkeni olarak da müşteri memnuniyeti, doluluk oranı, oda geliri ve tekrar gelen müşteri oranları dikkate alınmıştır. Örnekleme dâhil olan konaklama işletmelerinden toplanan ilgili girdi ve çıktı değişkenlerine ilişkin verileri Tablo 2.'de özetlenmiştir. Tabloda görüldügü üzere otellerin ortalama oda sayısı 44 ve personel sayısı ise 12 'dir. Bu ortalamalardan anlaşıldığı üzere belediye belgeli konaklama işletmeleri küçük ölçekli işletme standartlarını tam olarak sağlamaktadır (Thomas, 2000; Cetinel vd., 2009; Akbaba, 2012). Alan büyüklügü ortalama 4025 metrekare olan işletmelerin, ortalama oda fiyatı da yaklaşık 185 TL'dir. Diğer taraftan işletmelerin ortalama doluluk oranı yaklaşık \%71, tekrar gelen müşteri oranı ise \%42 düzeyindedir. Doluluk ortalamalarına bakıldığında tekrar gelen müşteri oranlarının genel ortalamaların yarısından fazlasını oluşturduğu görülmektedir. Tek başına bu veri bile diğer küçük işletmeler gibi belediye belgeli konaklama işletmelerinin performansında da tekrar gelen müşterilerin önemli etkisinin olduğunu ortaya koymaktadır (Barros, 2005).

Tablo 2. Belediye Belgeli Konaklama İşletmelerinin Özellikleri ( $\mathrm{n}=25)$

\begin{tabular}{lrc}
\hline Özellikler & Ortalama & Standart Sapma \\
\hline Oda Sayısı & 43,80 & 26,806 \\
\hline Yatak Sayısı & 115,60 & 76,826 \\
\hline Alan Büyüklüğü (metrekare) & 4024 & 4657,188 \\
\hline Personel Sayısı & 12,48 & 10,759 \\
\hline Doluluk Oranı (\%) & 71,40 & 14,897 \\
\hline Oda Geliri (TL) & 1146897,00 & 1154449,161 \\
\hline Faaliyet Yılı & 14,28 & 72,064 \\
\hline Ortalama Oda Fiyatı (TL) & 184,60 & 27,792 \\
\hline Tekrar Gelen Müşteri Oranı (\%) & 45,40 & 0,3663 \\
\hline Müşteri Memnuniyeti (5 üzerinden) & 3,98 & \\
\hline
\end{tabular}


İlgili girdi ve çıktı değişkenlerinin VZA sürecinde kullanılması için girdi kalemlerinden en az biri ile çıktı kalemlerden en az biri arasında anlamlı ve pozitif bir ilişki olması gerekir (Reynolds ve Thompson, 2007: 27). Bu ilişkinin test edilmesi amacıyla Spearman Korelasyon uygulanmış ve elde edilen sonuçlar Tablo 3.'te özetlenmiştir. Tabloda görüldüğü üzere müşteri memnuniyeti ile diğer değişkenler arasında anlamlı bir ilişki bulunmamaktadır. Buna karşın tekrar gelen müşteri oranları ile yatak sayısı arasında anlamlı ancak negatif bir ilişki ortaya çıkmıştır. Yani yatak sayısı az olan işletmelerde, tekrar gelen konuklar daha fazla olmaktadır. Bu sonuç, küçük otellerin konuklarıyla daha samimi ve daha iyi ilişkiler kurabildiği yargısını desteklemektedir (Barros, 2005). Ancak girdi ve çıktı değişken koşullarını sağlamamaktadır. Bu nedenle ilgili değişkenler analizden çıkarılmış ve oda sayısı, yatak sayısı, personel sayısı ve faaliyet alanı olmak üzere 4 girdi değişkeni ile yıllık doluluk oranı ve toplam gelir olmak üzere 2 çıktı değişkeni belirlenmiştir.

Tablo 3. Girdi ve Çıktı Değişkenlerinin Spearman Korelasyon Analizi Sonuçları

\begin{tabular}{|c|c|c|c|c|c|c|c|c|c|}
\hline \multicolumn{2}{|c|}{ Değişkenler } & 1 & 2 & 3 & 4 & 5 & 6 & 7 & 8 \\
\hline 1 & Oda Sayısı & 1,000 & & & & & & & \\
\hline 2 & Yatak Sayısı &, $893^{* *}$ & 1,000 & & & & & & \\
\hline 3 & Alan (metrekare) &, $744^{* *}$ &, $758^{* *}$ & 1,000 & & & & & \\
\hline 4 & Personel Sayısı &, $876^{* *}$ &, $881^{* *}$ & $684^{* *}$ & 1,000 & & & & \\
\hline 5 & Doluluk Oranı (\%) & 290 & ,304 & 164 & $436^{*}$ & 1,000 & & & \\
\hline 6 & Yıllık Oda Geliri (TL) &, $753^{* *}$ & $694^{* *}$ &, $620^{* *}$ &, $793^{* *}$ &, $546^{* *}$ & 1,000 & & \\
\hline 7 & Tekrar Gelen Müşteri (\%) &,- 243 &,$- 400^{*}$ &,- 090 &,- 302 &,- 140 &,- 270 & 1,000 & \\
\hline 8 & Müşteri Memnuniyeti &,- 251 &,- 165 &,- 191 &,- 137 &,- 010 &,- 014 &,- 046 & 1,000 \\
\hline
\end{tabular}

${ }^{*}$ Korelasyon 0.05 düzeyinde anlamlıdır.

** Korelasyon 0.01 düzeyinde anlamlıdır.

Nihai girdi ve çıktı değişkenleri belirlendikten sonra analizde kullanılacak VZA modeline karar verilmesi gerekir. Küçük oteller yoğun rekabet ortamı ve esnek talep koşullarında faaliyetlerini sürdürmektedir. Bu bağlamda küçük bir konaklama işletmesinin optimal ölçekte faaliyette bulunabilmesi çok zordur. Bununla birlikte sınırlı kaynaklarla yoğun rekabet ortamında faaliyetlerini yerine getiren kü̧̈ük işletme yöneticilerinin çıktılar üzerinde denetim gücü sınırlı kalmaktadır. Bu nedenle yapılan çalışmada, ölçeğe göre değişken getiri varsayımlı girdi odaklı BCC VZA modelinin kullanılmıştır. Win4DEAP ve EMS programlarıyla yapılan analiz sonuçları Tablo 4.'te gösterilmektedir. VZA sonuçları temel olarak etkin ve etkin olmayanlar şeklinde iki tür veri vermektedir. Eğer birimlerin etkinlik değeri 1 ise etkin, 1'den küçük ise etkin değil olarak nitelendirilmektedir. Tablo 4.'e bakıldığında 8 konaklama işletmesinin yani \%32'sinin etkin, kalan 17 işletmenin (\%68'nin) ise etkin olmadığı görülmektedir. En etkin üç konaklama işletmesi sırasıyla K20, K23 ve K6 işletmeleri; etkinlik düzeyi en düşük olanlar ise K14, K11 ve K13 işletmeleri olmuştur. Genel olarak bakıldığında belediye belgeli her üç konaklama işletmesinde sadece biri etkin olarak ortaya çıkmıştır. Tabloda da görüldüğü üzere belediye belgeli işletmelerin etkinlik ortalaması \%71'dir. Bu bağlamda ilgili karar birimlerinin etkinlikleri ortalama \%29 düzeyinde gelişme potansiyeli bulunmaktadır. Barros (2005:179) tarafından Portekiz'de 42 küçük konaklama işletmesi örnekleminde yapılmış benzer bir araştırmada, etkinlik ortalaması daha yüksek bir şekilde $\% 85$ olarak belirlenmiş ve otellerin yarısından fazlasının (\%57'sinin) etkin olduğu ortaya çıkmıştır. Tanzanya'da 38 küçük konaklama işletmesi örnekleminde yapılmış başka bir çalışmada ise 18'nin (\%47'sinin) etkin olarak belirlenmiştir (Sharma ve Sneed, 2008: 91). Etkinlik düzeyleri arasında ortaya çıkan farkın rekabet koşullarıyla ilişkilendirmesi mümkündür. Manavgat bölgesinde büyük ölçekli konaklama işletme sayısı küçük otellerden çok daha fazladır (Manavgat Ticaret ve Sanayi Odası , 2018). Dolayısıyla bu sonuç, büyük otellerle yaşanan yoğun rekabetin küçük işletme performansı üzerinde fazlasıyla etkili olduğunu ortaya koymaktadır. Babacan ve Özcan (2009: 176) tarafından Alanya'da bulunan 3, 4 ve 5 yıldızlı toplam 22 otel kapsamında yapılmış bir çalışmada ise 13'nün (\%59) etkin olarak belirlenmiştir. Diğer taraftan Lin vd. (2013: 330) Tayvan'da bulunan beş yıldızlı otel işletmeleri örnekleminde benzer VZA modeli 


\section{Yiğitoğlu - M. Şirin 12/3 (2020) 2297-2311}

ile yaptıkları araştırmalarında, etkinlik ortalamasının \%92 olduğunu ve işletmelerin yarısından fazlasının (\%56'sının) etkin olduğunu tespit etmiştir. Manasakis vd. (2013: 522) tarafından Girit Adası'nda bulunan 50 lüks otel örnekleminde yapılan bir araştırmada ise etkinlik ortalaması \%87 olarak ortaya çıkmıştır. Bu sonuçlar Fernandez ve Becerra (2015: 248) tarafından yapılmış bir araştırmada ortaya çıan büyük otellerin küçük otellere göre daha etkin olduğu şeklindeki araştırma bulgusunu desteklemektedir.

Tablo 4. Belediye Belgeli Konaklama İşletmelerinin Etkinlik Sonuçları

\begin{tabular}{|c|c|c|c|c|}
\hline $\begin{array}{c}\text { Karar } \\
\text { Birimleri }\end{array}$ & $\begin{array}{l}\text { Etkinlik } \\
\text { Değeri }\end{array}$ & $\begin{array}{c}\text { Süper Etkinlik } \\
\text { Değeri }\end{array}$ & $\begin{array}{l}\text { Süper Etkinlik } \\
\text { Sırası }\end{array}$ & $\begin{array}{l}\text { Referans Alınma } \\
\text { Sayısı }\end{array}$ \\
\hline K1 & 0,73 & 0,73 & 13 & - \\
\hline K2 & 0,63 & 0,63 & 17 & - \\
\hline K3 & 0,42 & 0,42 & 20 & - \\
\hline K4 & 0,75 & 0,75 & 12 & - \\
\hline K5 & 0,67 & 0,67 & 16 & - \\
\hline K6 & 1,00 & 1,90 & 3 & 8 \\
\hline K7 & 0,69 & 0,69 & 14 & - \\
\hline K8 & 0,38 & 0,38 & 22 & - \\
\hline K9 & 1,00 & 1,57 & 4 & 11 \\
\hline K10 & 0,53 & 0,53 & 18 & - \\
\hline K11 & 0,28 & 0,28 & 24 & - \\
\hline K12 & 0,94 & 0,94 & 9 & - \\
\hline K13 & 0,35 & 0,35 & 23 & - \\
\hline K14 & 0,27 & 0,27 & 25 & - \\
\hline K15 & 0,39 & 0,39 & 21 & - \\
\hline K16 & 1,00 & 1,31 & 5 & 6 \\
\hline K17 & 0,52 & 0,52 & 19 & - \\
\hline K18 & 0,67 & 0,67 & 15 & - \\
\hline K19 & 1,00 & 1,08 & 8 & 1 \\
\hline K20 & 1,00 & *big & 1 & 10 \\
\hline K21 & 0,78 & 0,78 & 11 & - \\
\hline K22 & 0,81 & 0,81 & 10 & - \\
\hline K23 & 1,00 & 8,00 & 2 & 13 \\
\hline K24 & 1,00 & 1,12 & 7 & 6 \\
\hline K25 & 1,00 & 1,16 & 6 & 1 \\
\hline
\end{tabular}

* Süper etkinlik değeri "big" en uç skorları ifade etmektedir. Bu karar birimleri, girdileri rastlantısal olarak arttırıldığında dahi etkin kalmaktadır.

Tablo 4.'te ayrıca etkin olan konaklama işletmelerinin etkin olmayan kaç işletmeye referans gösterildiği de yer almaktadır. Görüldüğü üzere etkin olmayan işletmelere ne fazla örnek olan işletmeler sirasıyla K23, K9 ve K20 işletmeleri olmuştur. Bu sonuca bağlı olarak etkin olmayan belediye belgeli işletmelerin yöneticileri, ilgili işletmelerin ortak uygulamalarını, pansiyon şekillerini, hizmet kalitesini ve diğer özelliklerini kendi işletmesine uyarlamalıdır. 
Araştırmada daha önce belirtildiği gibi girdi odaklı VZA modeli kullanılmıştır. Bu modelde etkin olmayan karar birimlerinin etkin olabilmesi için çıktıların sabit tutularak girdilerin ne düzeyde azaltılması gerektiği ortaya koyulmaktadır. Küçük ölçekli işletmeler sınırlı finans, beceri ve iş gücü kaynaklarına sahiptir. Bu bağlamda ilgili işletme yöneticilerinin çıktılar üzerinde etki gücü oldukça sınırlıdır. Böyle bir durumda girdi odaklı hareket etmek daha uygundur. Aşağıda yer alan Tablo 5.'te etkin olmayan 17 belediye belgeli konaklama işletmesinin etkin olmasını sağlayacak girdi hedefleri miktar ve değişim yüzdeleriyle gösterilmektedir. Tabloda görüldüğü üzere etkin olmayan işletmelerin oda sayısını ortalama \%46, yatak sayısını ortalama $\% 56$, personel sayısını ortalama $\% 44$, alan büyüklügünün ise ortalama $\% 52$ düzeyinde azaltması gerekmektedir. Bu noktada en fazla zorlanacak işletmeler beklendiği gibi etkinlik düzeyi en düşük olan işletmelerdir. Örneğin etkinlik değeri \%27 olan K14 işletmesi, girdilerini \%73 ve üzeri düzeylerde azaltması halinde etkinliğe ulaşabilmektedir. Yani işletmede 60 olan oda sayısının 16'ya, 120 olan yatak sayısının 33'e, 12 olan personel sayısının 3'e ve 2.700 metrekare olan alan büyüklügüünün 739 metrekareye düşürülmesi gerekmektedir.

Tablo 5. Etkin Olmayan Konaklama İşletmelerinin Hedef Girdi Değerleri

\begin{tabular}{|c|c|c|c|c|c|c|c|c|}
\hline \multirow{2}{*}{ KB } & \multicolumn{2}{|c|}{ Oda Sayısı } & \multicolumn{2}{|c|}{ Yatak Sayısı } & \multicolumn{2}{|c|}{ Personel Sayısı } & \multicolumn{2}{|c|}{ Alan Büyüklüğü } \\
\hline & $\begin{array}{l}\text { Hedef } \\
\text { (adet) }\end{array}$ & $\begin{array}{c}\text { Değişim } \\
\%\end{array}$ & $\begin{array}{l}\text { Hedef } \\
\text { (adet) }\end{array}$ & $\begin{array}{c}\text { Değişim } \\
\%\end{array}$ & $\begin{array}{l}\text { Hedef } \\
\text { (kişi) }\end{array}$ & $\begin{array}{c}\text { Değişim } \\
\%\end{array}$ & $\begin{array}{l}\text { Hedef } \\
\text { (m2) }\end{array}$ & $\begin{array}{c}\text { Değişim } \\
\%\end{array}$ \\
\hline K1 & 26 & $\% 32$ & 58 & $\% 47$ & 7 & $\% 30$ & 1.108 & $\% 54$ \\
\hline K2 & 38 & $\% 37$ & 88 & $\% 50$ & 13 & $\% 41$ & 2.028 & $\% 49$ \\
\hline K3 & 14 & $\% 59$ & 30 & $\% 64$ & 4 & $\% 60$ & 536 & $\% 79$ \\
\hline K4 & 12 & $\% 25$ & 24 & $\% 60$ & 3 & $\% 25$ & 889 & $\% 37$ \\
\hline K5 & 15 & $\% 38$ & 29 & $\% 65$ & 2 & $\% 33$ & 552 & $\% 54$ \\
\hline K7 & 23 & $\% 43$ & 55 & $\% 31$ & 11 & $\% 31$ & 2.068 & $\% 31$ \\
\hline K8 & 29 & $\% 61$ & 69 & $\% 72$ & 12 & $\% 60$ & 3.845 & $\% 62$ \\
\hline K10 & 13 & $\% 46$ & 30 & $\% 73$ & 4 & $\% 50$ & 839 & $\% 79$ \\
\hline K11 & 23 & $\% 72$ & 59 & $\% 78$ & 8 & $\% 73$ & 1.367 & $\% 80$ \\
\hline K12 & 19 & $\% 05$ & 48 & $\% 35$ & 5 & $\% 00$ & 939 & $\% 06$ \\
\hline K13 & 28 & $\% 65$ & 69 & $\% 75$ & 11 & $\% 63$ & 4.444 & $\% 78$ \\
\hline K14 & 16 & $\% 73$ & 33 & $\% 73$ & 3 & $\% 75$ & 739 & $\% 73$ \\
\hline K15 & 15 & $\% 70$ & 31 & $\% 61$ & 3 & $\% 63$ & 1.154 & $\% 62$ \\
\hline K17 & 17 & $\% 47$ & 39 & $\% 48$ & 3 & $\% 40$ & 1.311 & $\% 48$ \\
\hline K18 & 12 & $\% 52$ & 24 & $\% 60$ & 2 & $\% 33$ & 900 & $\% 57$ \\
\hline K21 & 28 & $\% 26$ & 62 & $\% 23$ & 5 & $\% 17$ & 1.552 & $\% 22$ \\
\hline K22 & 30 & $\% 32$ & 59 & $\% 33$ & 6 & $\% 50$ & 730 & $\% 19$ \\
\hline Ortalama & 21 & $\% 46$ & 47 & $\% 56$ & 6 & $\% 44$ & 1.471 & $\% 52$ \\
\hline
\end{tabular}

Diğer taraftan teorik olarak ortaya çıan girdi hedeflerine ulaşılması, uygulama açısından çok zor hatta olanaksız olarak görülebilir. Böyle bir durumda işletme yöneticileri girdilerle birlikte çıtılar üzerinde de odaklanmalıdır. Diğer taraftan tek bir girdi değişkeni üzerinde yapılacak her tasarruf mutlak etkinlik olmasa da etkinliğin kısmen geliştirilmesini sağlayabilir. Etkinlik değerleri yüksek olan küçük işletmeler ise etkinlik sürecinde daha avantajlıdır. Örneğin etkinlik ortalaması \%94 olan K12 20 olan odasının 19'a, 74 olan yatak sayısının 48'e, 5 olan personel sayısının aynı şekilde korunmasına ve 1000 metrekare alan büyüklügüünün 939'a düşürülmesi yeterlidir. Tabloda görüldüğü gibi her girdi değişkeni aynı oranda azaltılmamaktadır. K12 
işletmesinde oda sayısı ve alan büyüklüğünün \%5-6, yatak sayısının ise \%35 düzeyinde düşürülmesi gerekmektedir. Girdi düzeyleri azaltılırken her bir değişkenin önem düzeyi ve değişim koşulları ayrıca değerlendirilmelidir. Bu değişkenlerden personel sayısı ve yatak kapasitesinin kısa ve orta vadede azaltılması mümkündür. Ancak oda sayısı ve alan değişkenlerinin kısa vadede değiştirilmesi oldukça zordur. Diğer taraftan personel sayısının azaltılması daha kolay gözükse de konuk tutum ve davranışlarına etkisi daha derin olabilmektedir.

\section{Sonuç ve Tartışma}

Belediye belgeli konaklama işletmeleri gibi küçük ölçekli işletmeler sermaye, insan ve bilgi bakımından sınırlı kaynaklara sahiptir. Bu nedenle diğer işletmelere göre daha fazla riskle karşı karşıya kalmaktadır. Barsley ve Kleiner (1990: 30), her yıl küçük işletmelerin yaklaşık \%15'nin, beş yıl içinde ise yaklaşık \%80 gibi büyük bir kısmının iflas ettiğini ileri sürmüştür. Benzer şekilde Reynolds vd. (1994: 30), Avustralya'da küçük turizm işletmelerinin yaklaşık \%70'nin beş yıl içinde başarısız olduklarını belirtmiştir. Bu başarısızlıkta kullanılan performans değerleme yöntemlerinin de payının olduğu düşünülebilir. Çünkü "ölçülmeyen şey yönetilemez" anlayışından hareketle, doğru ölçülemeyen bir şeyin etkin yönetilemeyeceği ve buna bağlı olarak da başarılı sonuçlar sağlanamayacağı açıktır. Nitekim Bergin-Seers ve Jago (2007: 144) tarafından moteller üzerinde yapılan bir araştırmada, başarılı işletmelerde genellikle çok boyutlu performans ölçüm yaklaşımlarının kullanıldığı tespit edilmiştir.

VZA, az sayıda varsayımla, farklı nitelikte değişkenleri birlikte değerlendirerek etkinlik analizi yapabilen çok boyutlu performans yöntemlerinden biridir. Diğer performans ölçüm yöntemlerine göre en belirgin avantaj1; basit, ekonomik ve esnek olmasıdır. Dolayısıyla küçük ölçekli işletmelerin VZA ile kolay bir şekilde etkin ve kapsamlı performans değerlemesi yapabilmesi mümkündür. Manavgat'ta bulunan 25 belediye belgeli küçük konaklama işletmesi üzerinde yapılan çalışmada etkinlik ortalamasının $\% 71$ olduğu tespit edilmiştir. Bununla birlikte 8 işletmenin etkin, kalan 17'sinin ise etkin olmadığ 1 belirlenmiştir. Her üç işletmeden sadece birinin etkin olması, belediye belgeli küçük işletmelerin faaliyet riskinin çok fazla olduğunu göstermektedir. Bu durumun ortaya çıkmasında büyük ölçekli işletmelerin önemli bir payı olduğu düşünülmektedir. Çünkü Manavgat bölgesi ilçe düzeyinde 4 ve 5 yıldızlı büyük ölçekli işletme sayısının en fazla olduğu turizm bölgelerinden biridir. Dolayısıyla yerel ve merkezi yönetimlerin bölgedeki belediye belgeli işletmelere daha fazla destek olması gerekir. Bu noktada yerel yönetimler işletme sahip ve yöneticilerine mesleki ve teknik eğitimler verebilir. Merkezi yönetimler ise büyük işletme sayılarına sınır getirmek ya da bölgedeki belli noktaları küçük işletme yatırımlarına tahsis etmek gibi bir takım yasal düzenlemeler yapabilir.

Araştırmada girdi odaklı VZA modeli kullanılmıştır. Bu modelde etkin olmayan işletmelerin mevcut çıktı düzeyleriyle etkin olabilmesi için girdilerinde yapması gereken değişiklikler ortaya koyulmaktadır. Girdi odaklı analiz sonuçlarına göre etkin olmayan işletmelerin oda sayısı, yatak kapasitesi, personel sayısı ve fiziksel alan büyüklüklerini ortalama \%44-56 düzeylerinde azaltması gerekmektedir. Söz konusu hedefler etkinlik değeri ortalamadan büyük olan etkin olmayan işletmeler için uygulanabilir olurken, etkinlik değeri ortalamanın altında kalanlar için rasyonel olmayabilmektedir. Örneğin etkinlik değeri en düşük olan K14 ve K11 işletmelerinin girdilerini \%70'in üzerinde azaltması çok zordur. Bu durumdaki işletmelere girdilerini mümkün olabildiğince azaltmaları ve çıktılarını da arttırma konusunda daha fazla çaba göstermesi önerilmektedir. Diğer taraftan etkin olmayan işletmeler, faaliyetlerini ya da uygulamalarını en fazla referans gösterilen K23, K9 ve K20 işletmelerine göre düzenleyerek performanslarını geliştirebilir.

Geçmişte yapılmış araştırmalar, küçük işletmelerin performansı ile işletme sahibinin mesleki bilgi ve becerisi arasında yakın bir ilişki olduğunu ortaya koymuştur (Lerner ve Haber, 2000: 93; Reijonen 2008: 626). Bu bağlamda belediye belgeli işletme sahiplerinin etkin performans ölçümü de dâhil olmak üzere, turizmle ilgili konularda eğitim almaları ya da bu konuda yetkin bir uzmandan destek alması çok önemlidir.

Araştırmada örneklem ve yöntem bakımından bir takım sınırlılıklar bulunmaktadır. Öncelikle küçük işletme olarak belli bir bölgede, sınırlı sayıda ve sadece belediye belgesi olan işletmeler dikkate alınmıştır. VZA'da örneklemin yani karar birimlerinin homojen olması istenen bir durumdur. Bu bağlamda gelecekte bakanlık belgeli küçük işletmeleri de kapsayan daha geniş çaplı araştırmalar yapılabilir. Bu şekilde yapılacak bir araştırmada bölge ve belge türü bazında karşılaştırmalı performans değerlendirmeleri de mümkün olabilir. Diğer taraftan bu araştırmada katılımcılar, işletmeyle ilgili girdi ve maliyet verilerini paylaşmak istememiştir. $\mathrm{Bu}$ nedenle yazında sıklıkla kullanılan malzeme giderleri, işçilik giderleri ve genel giderler gibi personel 
maliyet girdileri dikkate alınamamıştır. Çalışmada kullanılan personel sayısı, yatak kapasitesi ve alan büyüklüğü gibi değişkenlerin her ne kadar finansal girdileri yansıttığı düşünülse de, gelecekte, farklı girdi ve değişkenleriyle yeni çalışmalar yapılabilir. Bunun dışında araştırma verileri, işletme sahip ya da yöneticilerinin görüşlerine dayanmaktadır. Dolayısıyla ilgili katılımcılar, bilerek ya da bilmeyerek gerçek verileri saklamış ya da saptırmış olabilir. Bu nedenle gelecekte yapılacak benzer çalışmalarda doküman incelemesi ve doğrudan gözlem gibi daha güvenilir veri toplama yöntemleri kullanılmalıdır. Küçük ölçekli işletmeler sınırlı kaynakları ve becerileri olması bakımından çevresel koşullara karşı çok daha fazla duyarlıdır. Bu bağlamda doğal ve ekonomik koşullar başta olmak üzere dış etmenlerin işletme performansı üzerinde önemli etkileri olabilmektedir. Gelecekte yapılacak çalışmalarda ilgili koşulların işletme performansı üzerindeki olası etkileri incelenebilir. VZA'da kullanılan girdi ve çıktı değişkenleri değiştikçe örneklemin performans düzeyleri de değişmektedir. Dolayısıyla girdi ve çıktı değişkenlerinin belirlenme süreci VZA çalışmalarının en kritik aşamalarından biridir. Bu bağlamda gelecekte yapılacak çalışmalarda ilgili değişkenlerin belirlenmesi sürecinde nitel ya da nicel veri toplama tekniklerinin kullanılması önerilmektedir. Son olarak, büyük ve küçük ölçekli otellerin performansı düşük ve yüksek sezonlarda ayrı ayrı olarak belirlenerek hem sezon hem de işletme büyüklüğü bazında karşılaştırmalı değerlendirmeler yapılabilir.

\section{Kaynakça}

Ahmad, S. Z. and Muhammad Arif, A. M. (2016). Entrepreneurial characteristics, motives, and business challenges: exploratory study of small- and medium-sized hotel businesses. International Journal of Hospitality and Tourism Administration, 17(3), 286-315.

Akal, Z. (2005). İşletmelerde Performans Ölçüm ve Denetimi: Çok Yönlü Performans Göstergeleri, (6. Baskı), Ankara: Milli Prodüktivite Merkezi Yayınları.

Akbaba, A. (2012). Characteristics of small hospitality businesses : a study in an urban setting in Turkey. FIU Hospitality Review, 30(2), 42-73.

Aksu, A. A. ve Köksal, C. D. (2005). Bağımsız ve zincir otel işletmelerinin veri zarflama analizi ile etkinliklerin karşılaştırılması: Antalya bölgesinde bir çalışma. İktisat İşletme ve Finans, 20(235), 97-107.

Assaf, A. G. and Tsionas, M. (2018). Measuring hotel performance: toward more rigorous evidence in both scope and methods. Tourism Management, 69, 69-87.

Atkins, M. H.. and Lowe, J. F. (1997). Sizing up the small firm: UK and Australian experience. International Small Business Journal, 15(3), 42-55.

Avcıkurt, C., Altay, H. and İlban, M. O. (2011). Critical success factors for small hotel businesses in Turkey: An exploratory study. Cornell Hospitality Quarterly. 52(2), 153-164.

Avkıran, N. K. and Parker, B. R. (2010). Pushing the DEA research envelope. Socio-Economic Planning Sciences, 44(1), 1-7.

Babacan, A. ve Özcan, S. (2009). Alanya bölgesi otellerinin göreli etkinliğinin belirlenmesi: bir veri zarflama analizi tekniği uygulaması. Mustafa Kemal Üniversitesi Sosyal Bilimler Enstitüsü Dergisi, 6(12), 176-189.

Baker, M. and Riley, M. (1994). New perspectives on productivity in hotels: some advances and new directions. International Journal of Hospitality Management, 13(4), 297-311.

Banker, R. D., Charnes, A. and Cooper, W. W. (1984). Some models for estimating technical and scale inefficiencies in data envelopment analysis, Management Science, 30(9), 1078-1092.

Banker, R. D. and Morey, R. C. (1986). Efficiency analysis for exogenously fixed inputs and outputs. Operations Research, 34(4), 513-521.

Barros, C. P. (2005). Evaluating the efficiency of a small hotel chain with a Malmquist productivity index. International Journal of Tourism Research, 7(3), 173-184.

Barros, C. P. and Dieke, P. U. (2008). Technical efficiency of African hotels. International Journal of Hospitality Management, 27(3), 438-447. 
Barros, C. P. and Mascarenhas, M. J. (2005). Technical and allocative efficiency in a chain of small hotels. International Journal of Hospitality Management, 24(3), 415-436.

Barros, C. A. P. and Santos, C. A. (2006). The measurement of efficiency in Portuguese hotels using data envelopment analysis. Journal of Hospitality \& Tourism Research, 30(3), 378-400.

Barsley, G. and Kleiner, B. (1990). Small business management: Ensuring your clients success. National Public Accountant, 35(2), 30 -33

Bergin-Seers, S. and Jago, L. (2007). Performance measurement in small motels in Australia: (Funded by the Sustainable Tourism Co-operative Research Centre). Tourism and Hospitality Research, 7(2), 144-155.

Bititci, U., Cocca, P. and Ates, A. (2016). Impact of visual performance management systems on the performance management practices of organisations. International Journal of Production Research, 54(6), 1571-1593.

Budak, H. (2011). Veri Zarflama Analizi ve Türk Bankacılık Sektöründe Uygulaması. Marmara Üniversitesi Fen Bilimleri Dergisi, 23(3), 95-110.

Buhalis, D. and Main, H. (1998), Information technology in peripheral small and medium hospitality enterprises: strategic analysis and critical factors, International Journal of Contemporary Hospitality Management, 10 (5), 198-202.

Capital (2013). Etkinlik mi Verimlilik mi?, https://www.capital.com.tr/kose-yazisi/kose-yazisi-433671/etkinlikmi-verimlilik-mi (Erişim Tarihi: 12 Haziran 2020).

Cetinel, F., Yolal, M. and Emeksiz, M. (2009). Human resources management in small- and medium-sized hotels in Turkey. Journal of Human Resources in Hospitality and Tourism, 8(1), 43-63.

Charles, V. and Kumar, M. (2012). Data Envelopment Analysis And Its Applications to Management, UK: Cambridge Scholars Publishing.

Charnes, A., Cooper, W. W. and Rhodes, E. (1978). Measuring the Efficiency of Decision Making Units, European Journal of Operational Research, 2(6), 429-444.

Chibili, M. (2017). Modern Hotel Operations Management, (1st Edition), UK: Routledge.

De Jorge, J. and Suarez, C. (2014). Productivity, efficiency and its determinant factors in hotels. The Service Industries Journal, 34(4), 354-372.

Doğan, N. Ö. ve Tanç, A. (2008). Konaklama işletmelerinde veri zarflama analizi yöntemiyle faaliyet denetimi: Kapadokya örneği. Atatürk Üniversitesi İktisadi ve İdari Bilimler Dergisi, 22(1), 239-259.

Fernandez, M. A. and Becerra, R. (2015). An analysis of Spanish hotel efficiency. Cornell Hospitality Quarterly, 56(3), 248-257.

Haksever, C. and Render, B. (2013). Service Management: An Integrated Approach to Supply Chain Management And Operations, New Jersey: Pearson Education.

Haynes, B.P. (2007). An evaluation of office productivity measurement, Journal of Corporate Real Estate, 9(3), 144-155.

Honma, S. and Hu, J. L. (2012). Analyzing Japanese hotel efficiency. Tourism and Hospitality Research, 12(3), 155167.

Hruschka, H. (1986). Ansätze Der Effizienzmessung von Betrieben, Journal für Betriebswirtschaft, 36(2), 76-85.

İyitoğlu, V. ve Şirin, M. (2019). Küçük Ölçekli Konaklama İşletmelerinde Etkinlik Analizi, Birdir, K. (Ed.) 3. International Congress on Future of Tourism: Innovation, Entrepreneurship and Sustainability, 26-28 September, Mersin/Turkey, 746-752.

Kaplan, R. S. and Norton, D. P. (2001). Transforming the balanced scorecard from performance measurement to strategic management: Part I. Accounting horizons, 15(1), 87-104. 
Komppula, K. and Reijonen, H. (2006). Performance determinants in small and micro tourism business. Tourism Review, 61(4), 13-20.

Kültür ve Turizm Bakanlığ1 (2019). Tesis İstatistikleri, https://yigm.ktb.gov.tr/TR-201131/tesisistatistikleri.html (Erişim Tarihi: 25 Ekim 2019).

Lerner, M. and Haber, S. (2000). Performance factors of small tourism ventures: The interface of tourism, entrepreneurship and the environment. Journal of Business Venturing, 16(1), 77-100.

Lin, H. T., Hsieh, C. Y., Lin, S. L. and Shih, M. L. (2013). Two-Stage Evaluation of International Tourist Hotels in Taiwan Using Data Envelopment Analysis. Journal of interdisciplinary mathematics, 16(4-5), 317-335.

Liu, J. S., Lu, L. Y., Lu, W. M. and Lin, B. J. (2013). Data Envelopment Analysis 1978-2010: A Citation-Based Literature Survey, Omega, 41(1), 3-15.

Manasakis, C., Apostolakis, A. and Datseris, G. (2013). Using data envelopment analysis to measure hotel efficiency in Crete. International Journal of Contemporary Hospitality Management. 25(4), 510-535.

Manavgat Ticaret ve Sanayi Odası (2018). MATSO 2018 Ekonomik Raporu, https://drive.google.com/file/d/1np3Og2FLr7atGzhhJsF1MHkU1MqzUNye/view (Erişim Tarihi: 27 Haziran 2019).

Mevzuat Bilgi Sistemi (2019). Küçük ve Orta Büyüklükteki İşletmelerin Tanımı, Nitelikleri ve Sınıflandırılması HakkındaYönetmelik,https://www.mevzuat.gov.tr/Metin.Aspx?MevzuatKod=3.5.20059617\&MevzuatI liski=0\&sourceXmlSearch=k\%C3\%BC\%C3\%A7\%C3\%BCk (Erişim Tarihi: 11 Şubat 2020).

Min, H., Min, H., Joo, S. J. and Kim, J. (2009). Evaluating the financial performances of Korean luxury hotels using data envelopment analysis. The Service Industries Journal, 29(6), 835-845.

Mohammad, A. A. (2016). How can small and medium-sized hotels compete with international hotel chains? Egypt as a case study. Tourism Review International, 20(1), 57-70.

Morrison, A. (1998). Small firm statistics: A hotel sector focus. Service Industries Journal, 18(1), 132-142.

Morrison, A. and Conway, F. (2007). The status of the small hotel firm the status of the small hotel firm. The Service Industries Journal, 27(1), 47-58.

Morrison, A. and Teixeira, R. (2004). Small business performance: A tourism sector focus. Journal of Small Business and Enterprise Development, 11(2), 166-173.

Neely, A., Gregory, M. and Platts, K (1995). Performance measurement systems design: A literature review and research agenda. International Journal of Operations \& Production Management, 15 (4), 80-116.

Oktay, E. ve Özgür, E. (2008). Konaklama Tesisleri Etkinlik Analizi. Afyon Kocatepe Üniversitesi Sosyal Bilimler Enstitüsü Dergisi, 10(1), 163-175.

Özdemir, A. ve Demireli, E. (2013). Ağırlık Kısıtlı Veri Zarflama Analizi İle Mevduat Bankalarının Etkinlik Ölçümüne Yönelik Bir Uygulama. Uluslararası Yönetim İktisat Ve İşletme Dergisi, 9(19), 215-238.

Parkan, C. (1996) Measuring the performance of hotel operations. Socio-Economic Planning Sciences, 30(4), 257292.

Poldrugovac, K., Tekavcic, M. and Jankovic, S. (2016). Efficiency in the hotel industry: An empirical examination of the most influential factors. Economic research-Ekonomska istraživanja, 29(1), 583-597.

Prokopenko, J. (2005). Verimlilik Yönetimi Uygulamalı El Kitabı. (Çev. Baykal, O., Atalay, N. ve Fidan, E.), Ankara: Milli Prodüktivite Merkezi Yayınları.

Pulina, M., Detotto, C. and Paba, A. (2010). An investigation into the relationship between size and efficiency of the Italian hospitality sector: A window DEA approach. European Journal of Operational Research, 204(3), 613-620.

Ramanathan, R. (2003). An introduction to data envelopment analysis: A tool for performance measurement. Yeni Delhi: Sage Publications. 
Reijonen, H. (2008). Understanding the small business owner: What they really aim at and how this relates to firm performance. Management Research News, 13(8), 616 -629.

Reynolds, W., Savage, W. and Williams, A. (1994). Your own business: A practical guide to success. Melbourne: Thomas Nelson.

Reynolds, D. and Thompson, G. M. (2007). Multiunit restaurant productivity assessment using three-phase data envelopment analysis. International Journal of Hospitality Management, 26(1), 20-32.

Rey-Marti, A., Felicio, J. A. and Rodrigues, R. (2017). Entrepreneurial attributes for success in the small hotel sector: a fuzzy-set QCA approach. Quality and Quantity, 51(5), 2085-2100.

Sami, B. A. and Mohamed, G. (2014). Determinants of tourism hotel profitability in Tunisia. Tourism and Hospitality Research, 14(4), 163-175.

Sainaghi, R. (2010). Hotel performance: state of the art. International Journal of Contemporary Hospitality Management. 22(7), 920-952.

Shahzad, F., Luqman, R. A., Khan, A. R. and Shabbir, L. (2012). Impact of organizational culture on organizational performance: An overview. Interdisciplinary Journal of Contemporary Research In Business. 3 (9), 975-985.

Sharma A. and Sneed, J. (2008). Performance analysis of small hotels in Tanzania. Journal of Services Research, Special Issue (8), 83-100.

Sigala, M. (2004). Using data envelopment analysis for measuring and benchmarking productivity in the hotel sector. Journal of Travel \& Tourism Marketing, 16(2-3), 39-60.

Sink, D. S. (1985). Productivity Management: Planning, Measurement and Evaluation, Control and Improvement. New York: Wiley.

Tarım, Ş., Dener, H. I. and Tarım, Ş. A. (2000). Efficiency measurement in the hotel industry: output factor constrained DEA application. Anatolia, 11(2), 111-123.

Thomas, R. (2000). Small firms in the tourism industry: some conceptual issues. International Journal of Tourism Research, 2(5), 345-353.

Tone, K. (2017). Advances in DEA Theory and Applications, With Extensions to Forecasting Models. (1st Edition). UK: Wiley.

Uyar, S. ve Alış, M. (2014). Konaklama işletmelerinde veri zarflama analizi yöntemiyle faaliyet denetimi uygulaması. Dokuz Eylül Üniversitesi İktisadi İdari Bilimler Fakültesi Dergisi, 29(2), 107-136.

Wöber, K.W. (2000). Benchmarking hotel operations on the internet: A data envelopment analysis approach. Information Technology and Tourism, 3 (3/4), 195-212.

Wöber, K. W. (2007). Data envelopment analysis. Journal of Travel and Tourism Marketing, 21(4), 91-108.

Ye, S., Xiao, H. and Zhou, L. (2019). Small accommodation business growth in rural areas: Effects on guest experience and financial performance. International Journal of Hospitality Management, 76, 29-38.

Yılmaz, Y. (2013). Impact of strategy on efficiency in the luxury hotel industry of Turkey. Anatolia, 24(2), 206220.

Yükçü, S. ve Atagan, G. (2009). Etkinlik, etkililik ve verimlilik kavramlarının yarattığı karışıklık. Atatürk Üniversitesi İktisadi ve İdari Bilimler Dergisi, 23(4), 1-13.

Zhou, Z., Huang, Y. and Hsu, M. K. (2008). Using data envelopment analysis to evaluate efficiency: An exploratory study of the Chinese hotel industry. Journal of Quality Assurance in Hospitality $\mathcal{E}$ Tourism, 9(3), 240-256. 